\title{
MINERAL RESOURCE POTENTIAL OF THE HELLS GATE ROADLESS AREA, GILA COUNTY, ARIZONA
}

\section{SUMMARY REPORT}

\author{
By
}

\author{
Clay M. Conway ${ }^{1}$, Robert A. McColly ${ }_{1}^{2}$, \\ Sherman P. Marsh', Dolores M. Kulik', \\ Ronny A. Martin ${ }^{1}$, and James E. Kilburn' 1
}

\section{STUDIRS RELATED TO WILDERNESS}

Under the provisions of the Wilderness Act (Public Law 88-577, September 3, 1964) and related acts, the U.S. Geological Survey and the U.S. Bureau of Mines have been conducting mineral surveys of wilderness and primitive areas. Areas officially designated as "wilderness," "wild," or "canoe" when the act was passed were incorporated into the National Wilderness Preservation System, and some of them are presently being studied. The act provided that areas under consideration for wilderness designation should be studied for suitability for incorporation into the Wilderness System. The mineral surveys constitute one aspect of the suitability studies. The act directs that the results of such surveys are to be made available to the public and b? submitted to the President and the Congress. This report discusses the results of a mineral survey of the Hells Gate Roadless Area (3-021), Tonto National Forest, Gila County, Arizona. The area was classified as a further planning area during the Second Roadless Area Review and Evaluation (RARE II) by the U.S. Forest Service, January 1979.

\section{SUMMARY}

Tin-bearing alkali granite, granophyre, and rhyolite of Early Proterozoic age underlie most of the Hells Gate Roadless Area. On the basis of geologic and geochemical evidence, a low to moderate resource potential exists for tin along the north and west margins of the area in the upper part of a granite body and in structurally overlying granophyre. A low resoure? potential for tin exists in central to southern parts of the area in intrusive and extrusive rhyolite. The resource potential for barite in veins along Tertiary faults is low. Except for geochemical data, there is no evidence of resource potential for gold, silver, copper, and lead in the area.

\section{INTRODUCTION}

\section{GEOGRAPHIC SETTING}

The Hells Gate Roadless Area comprises approximately 31,200 acres in the northern part of the Tonto National Forest in Gila County, Ariz. (fig. 1). The area is roughly a 4by 15-mi strip along a deeply incised segment of upper Tonto Creek. Elevations range from $3,000 \mathrm{ft}$ in the lower gorge to $6,000 \mathrm{ft}$ in hills above the upper gorge; local relief in the canyon is commonly greater than $1,000 \mathrm{ft}$. The roadless area lies in the central part of Tonto Basin which consists of Tonto Creek and its tributaries draining the Mogollon Rim and the northern Sierra Ancha between Payson and Young.

The roadless area may be reached by four-wheel-drive trails from Little Green Valley on the north and from Pleasant Valley on the southeast. These roads are connected by a pack trail that crosses the area at Hells Gate (the confluence of Tonto and Haigler Creeks); descent into the Tonto Creek gorge is difficult elsewhere. A good dirt road from the Chamberlain Trail extends to the Ellinwood Ranch on Gordon Creek, $1.5 \mathrm{mi}$ east of the roadless area. A four-wheel-drive track extends from there westward nearly to Hells Gate. The southwestern part of the area can be reached by a fourwheel-drive road from Arizona Highway 260 a few miles east of Star Valley to Houston Pocket near Tonto Creek.

Vegetation is light to moderately dense. Intermediate to higher elevations are forested with pinion pine, alligator juniper, several varieties of oak, and stands of ponderosa pine above 5,000 ft. Succulents, cactus, and chapparal are common at lower elevations. Soil cover is light and bedrock exposure is excellent.

\section{MINING ACTIVITY}

Little mineral exploitation has occurred in the Tonto Basin. There was a short period of moderately successful small-seale gold mining in the late 1800's in Proterozoic diorite south and west of Payson. A few small base- and precious-metal mines have operated intermittently in Proterozoic volcanic and clastic strata south and east of the roadless area. A small barite vein a few miles west of the roadless area was mined in the 1970 's. There are no active claims in the roadless area and only a few small prospect pits.

\section{CURRENT INVESTIGATION}

From 1980 through 1982 the U.S. Geo'ogical Survey and the U.S. Bureau of Mines conducted geologic mapping, a geochemical survey of rocks and drainage sediments, gravity and aeromagnetic surveys, and investigations of mines, prospects, and mining history. This report sunmarizes the findings of these surveys as they pertain to the mineral resource potential of the Hells Gate Roadless Area.

\section{GEOLOGY, GEOCHEMISTRY, AND GEOF "YSICS PERTAINING TO MINERAL RESOURCE AS'TESSMENT}

\section{GEOLOGY}

The Hells Gate Roadless Area is underlain entirely by rocks of Early Proterozoic age (1.7 b.y.) and small local deposits of unconsolidated Tertiary and Quaternary gravel and sand (see simplified geologic base of reso urce potential map). The Middle Proterozoic Apache Group (1.2 b.y.) and

${ }_{2}^{1}$ U.S. Geological Survey

${ }^{2}$ U.S. Bureau of Mines 
Paleozoic sedimentary rocks are widely exposed within a few miles of the roadless area. The Apache Group rests unconformably on the Early Proterozoic basement, and the Paleozoic rocks rest unconformably on both the Apache Group and the Early Proterozoic rocks. Following late Tertiary normal faulting and the consequent development of the Mogollon Rim and the central Arizona mountain and valley terrane, both the Apache Group and the Paleozoic strata were eroded from the Hells Gate area. Some sand and gravel deposits in the roadless area rest upon Tertiary faults and were probably deposited by ancestral streams of the Tonto Creek drainage system. However, some deposits, especially the thicker deposits at higher elevations, may be equivalent to extensive upper Miocene deposits west of Payson which predate the Tertiary faulting.

Early Proterozoic rocks in the vicinity of the roadless area were briefly discussed by Darton (1925), Lausen and Wilson (1925), Wilson (1922, 1939), and Putman and Burnham (1963). The first detailed study of the Proterozoic rocks in the area was by Gastil (1958), who mapped eastern parts of the Hells Gate Roadless Area. He found that extrusive rhyolite which is widely exposed in the area is one of the uppermost units in a stratigraphic succession which is exposed mostly southeast of the area. He postulated that this rhyolite and the extensive intrusive rhyolite, granophyre, and granite of the Tonto Basin area were genetically and temporally related. Conway (1976) mapped all except a small southern part of the Hells Gate area and found that a quartzite in the area rests depositionally on the extrusive rhyolite. He refined and documented the stratigraphy and structure of the area and described the physical and petrogenetic evolution of the deeply eroded volcanic complex composed of rhyolite, granophyre, and granite. This work supports Gastil's suggested cogenetic relation for the felsic igneous rocks.

Early Proterozoic stratified rocks and sheets of intrusive rocks exposed in the Hells Gate Roadless Area occupy the axis of a broad northeast-trending synclinorium. Quartzite (Xq) and underlying alkalic extrusive rhyolite (Xer) constitute the upper third of a 20,000-ft-thick stratified sequence exposed in the axis and southeast limb of the synclinorium. Sedimentary, volcaniclastic, and volcanic rocks (Xsv) of the lower two-thirds of the sequence lie outside the Hells Gate Roadless Area. Intrusive alkalic rhyolite (Xir), granophyre (Xgp), and granite $(\mathrm{Xg})$ occupy the axis and northwestern limb of the synclinorium and were intruded beneath and into the extrusive rhyolite and quartzite.

The extrusive rhyolite and associated hypabyssal felsic rocks constitute a volcanic complex which evolved at a basin margin whose constructs were largely emergent, and most of the extrusive rhyolite is terrestrial ash-flow tuff. Quartz arenite was deposited in high-energy fluvial or marine environments both before and after the major eruptive episode.

A diorite-gabbro complex (Xd) with pendants of volcanic and volcaniclastic rocks is exposed a few miles west of the Hells Gate Roadless Area. These rocks are older than the granite and granophyre and are possibly older than the stratified sequence described above.

Folds of the synclinorium and thrust faults in Tonto Basin developed in a Proterozoic compressional event (Mazatzal orogeny, Wilson, 1939). Stratified rocks are openly to isoclinally folded and weakly to intensely foliated. Massive igneous and quartzite bodies are weakly to imperceptibly foliated. During this orogenic event the Proterozoic rocks of the region were metamorphosed in the greenschist facies. Northeast- to north-trending faults, possibly representing a late stage of the Mazatzal orogeny (Conway and others, 1982) have normal to left-lateral components of offset.

The northeast- to north-trending faults are locally occupied by veins of white quartz or quartz-healed fault breccia as much as $12 \mathrm{ft}$ wide. Locally, the country rocks are extensively altered (apparently hematitized and sericitized) near the quartz veins. No prospects were found in the veins or altered rock. Samples from several quartz veins and nearby altered rocks within the roadless area yielded no anomalous metal values; however, quartz veins at Bearhide Canyon, $1 \mathrm{mi}$ north of the roadless area, are mineralized. Thrust faults both within and west of the Hells Gate Roadless
Area contain local extensive breccia zones which are healed with silica and hematite. Agate is abundant in the fault breccia at Agate Mountain $1 \mathrm{mi}$ west of the roadless area. Analyses of these rocks yielded no anomalous metal values.

Both primary (magmatic) and secondary (hydrothermal) characteristics of the felsic igneous rocks, particularly the granite, suggest potentially ore-forming conditions. Ubiquitous fluorite, disseminated tourmaline in some units, and miarolitic cavities in many units indicate the magma was volatile rich (Conway, 1976). Paucity of pegmatites in the granite may be explained by the high-level of intrusion where fluids readily migrated upward under low lithostatic pressure. One of the oldest extrusive rhyolites (southeast of the Hells Gate Roadless Area) contains topaz. Fluorite, tourmaline, and topaz are minerals commonly formed from volatile-rich highly differentiated magmas which may accompany enrichments in lithophile elements (Taylor, 1979; Burt and others, 1982).

The extrusive rhyolite and associated hypabyssal rocks are extensively altered. Primary ferromagnesian minerals have been almost universally converted to hematite and either muscovite or sericite. The hematite is finely divided and disseminated, particularly in feldspar equilibrated at very low temperatures. In the upper parts of the granite, rare massive tourmalinization indicates flooding by hydrothermal fluids. These alterations probably accompanied hydrothermal activity during the active history of the volcanic complex.

\section{DRAINAGE-SEDIMENT GEOCHEMISTRY}

Sediment samples were taken at 85 sites chosen to allow reconnaissance analysis of detritus representing all small drainage systems $\left(0.2-1 \mathrm{mi}^{2}\right)$ in the roadless area. In the field, loose sediments were screened to pass 9 mesh. From these samples, the minus-80-mesh fraction was separated in the laboratory for semiquantitative spectrographic analysis; these analyses are referred to in this report as bulksediment analyses. A heavy-mineral sample was also collected at each site by hand panning. In the laboratory, magnetic minerals were removed from these samples with a hand magnet, and a further separation of heavy minerals was made with the heavy liquid bromoform (specific gravity 2.86). Ferromagnesian silicate minerals were then removed from the samples with the Frantz isodynamic separator at a setting of 0.6 amperes. This high-density fraction was then fused in a tetra-borate flux in preparation for semiquantitative spectrographic analysis. Dilution by the flux results in an approximately two-fold increase in detection level over that for the bulk-sediment analyses (see tables 1 and 2). Analyses of the heavy-mineral concentrates are referred to in this report as concentrate analyses. All bulk-sediment samples and 79 panned-concentrate samples (insufficient material for 6 samples) were analyzed for thirty-one elements. In the following sections and in the explanation on the accompanying mineral resource potential map, analyses for certain elements in certain areas are referred to as being "high" or "anomalous." Levels for given elements considered to be "high" or "anomalous" for the purpose of this report are indicated in tables 1 and 2.

\section{The tin suite}

Heavy-mineral concentrates in most of the roadless area are characterized by high values of tin, beryllium, niobium, lanthanum, and yttrium (the tin suite). Boron is locally high in both bulk sediments and concentrates. The distribution of these elements clearly indicates their source as the silicic igneous units, granite, granophyre, and intrusive and extrusive rhyolite, which underlie most of the area. The highest concentrations are from drainages underlain by the upper part of the granite pluton and by granophyre.

Cassiterite, identified in the panned concentrates, is probably the source of the tin. Beryllium, niobium, lanthanum, and yttrium may reside in the cassiterite or in other nonmagnetic heavy minerals such as zircon, xenotime, or monazite. The source of the cassiterite is unknown; it may be sparsely disseminated in the igneous rocks. However, some drainages contain unusually high amounts of tin and 
other elements, which suggests that greisen zones may be present.

Areas of low to moderate $\left(\mathrm{Sn}_{1}\right)$ and low $\left(\mathrm{Sn}_{2}\right)$ resource potential for tin and criteria for their classification are shown on the accompanying mineral resource potential map. Area $\mathrm{Sn}_{1}$ has, in addition to higher tin, beryllium, niobium, and yttrium in panned concentrates (fig. 2), local high values of niobium, lanthanum, yttrium, lead, and tin in bulk sediments. High copper and bismuth values were measured in a few panned concentrates. Area $\mathrm{Sn}_{2}$ is characterized by generally lower concentrations of tin, beryllium, niobium, and yttrium and higher concentrations of lanthanum in concentrates (fig. 2).

Five localities (areas 1-5, accompanying map sheet and fig. 3) are characterized by unusually high concentrations of the tin suite and of other metals in panned concentrates and (or) bulk-sediment samples. Four are outside the roadless area but within area $\mathrm{Sn}_{1}$ and one is within the roadless area in area $\mathrm{Sn}_{2}$.

North of Gisela two adjacent sampled drainages (area 1 , drainages outlined on map) have anomalous values of a remarkably large suite of elements. There are high contents of tin, beryllium, niobium, lanthanum, yttrium, arsenic, thorium, molybdenum, bismuth, and barium in the panned concentrates, and high contents of niobium, lanthanum, yttrium, lead, molybdenum, thorium, tin, and iron in the bulk sediments. A quartz vein along the north-northeast-trending fault which crosses the northern of the two drainage areas is not a likely source of these anomalies because it does not have high metal contents.

Two to three miles west of the roadless area near the Baronite barite prospect, several adjoining drainage systems (within area 2) contain high values of lanthanum, niobium, silver, copper, lead, arsenic, and barium in panned concentrates. Bulk sediments yielded high amounts of silver, copper, lead, niobium, and yttrium. The high copper contents are the only anomalous bulk-sediment copper values in the entire study area. The sediments are from a large area in the granite which is extensively oxidized and possibly brecciated. The widespread iron oxide minerals may have formed from alteration of sulfides. Original mineralization may be related to the nearby Agate Mountain thrust fault, but samples of fault breccia containing silica and hematite cement from the thrust fault at Agate Mountain, $21 / 2 \mathrm{mi}$ to the southwest, have no anomalous metal values.

The mineralized area at Mud Spring (area 3) is defined on the basis of prospect pits and indications of mineralization and alteration. No stream sediments were collected from drainages in this area.

Panned-concentrate samples from two drainages in the vicinity of the Bearhide Canyon copper-gold-silver prospects (area 4) have high values of tin, beryllium, yttrium, tungsten, boron, and thorium. Bulk-sediment samples have high values of thorium, lead, tin, boron, and silver. Most high values including those for silver are not from the Bearhide Canyon drainage, however, which suggests that the metal content of the sediment samples may be related to mineralization in the late Miocene fault that passes through both drainages rather than to the mineralization at the Bearhide Canyon prospects.

North and south of Tonto Creek a few miles west of Hells Gate, panned concentrates from a number of drainages (area 5) yielded slightly anomalous contents of tin, beryllium, lanthanum, yttrium, niobium, silver, thorium, and boron. Bulk-sediment samples from the same area have high contents of lead, silver, bismuth, manganese, and titanium. Dump material from a shallow shaft in area 5 along Tonto Creek has been washed away. The nature of the presumed mineralization was not determined.

\section{Barite, tungsten, and lead}

Three zones of high barium values in concentrates are shown on the mineral resource potential map. These zones coincide closely with east-west Miocene faults. The Gisela (Spook) barite mine and Baronite barite prospect lie on or near Miocene faults in these zones. The northern two zones are well defined and correspond closely with the Star Valley fault and with a southwestward extrapolation of the Mud
Spring fault. Faults (not shown on the map) in the vicinity of Hells Gate may be part of a fault system connected to the Mud Spring fault. The broad, less well-defined southern barium zone contains the Willow Spring fault: on which the Gisela (Spook) barite deposit occurs. Several samples from drainages eastward on this fault are low in barite.

Tungsten and lead contents in panner concentrates also tend to be higher in the vicinity of the Miocene faults although the anomalies are not as pronounced as are the barium anomalies. The tungsten content in most samples is below the detection level $(100 \mathrm{ppm})$. Of the 13 samples in which tungsten was measured (100 to $500 \mathrm{ppm}), 10$ are in the high barium zones and 11 are from drainages crossed by Miocene faults (including one sample on the Diamond Rim fault).

\section{Chromium, nickel, and vanadium}

In two localities (areas 6 and 7), each with two drainage samples, bulk sediments contain anomalously high values of .chromium, nickel, and vanadium. In area 6 cobalt is also high. In both areas bulk sediments also have high values of iron and manganese and in area 7 they contair high values of calcium and magnesium. The absence in the panned concentrates of anomalies for these elements, except for calcium and magnesium, indicates that the metals are in a magnetic iron-rich phase. Numerous bulk samples with comparable iron levels collected elsewhere in the area do not have the anomalous suite of chromium, nickel, vanadium, and cobalt. These samples contain only a few scattered high values, usually of only one of these elements.

Concentrations of chromium, nickel, cobalt, and vanadium are commonly associated with iron- and magnesium-rich mafic and ultramafic rocks. A rea 6 is underlain mostly by Tertiary and Quaternary gravel and sand, with minor felsic igneous rocks, and area 7 is underlain by felsic igneous rocks. Numerous other drainages urderlain by the same geologic units have no such anomalies. The sources of the ferro-alloy metals are not known, but are surely small.

\section{Gold}

A number of old claims along Tonto $\mathrm{C}^{+}$eek may have been worked for placer gold. Gold was not detected (detection limit $0.15 \mathrm{ppm}$ ) in 16 samples of panned heavy-mineral concentrates taken along the length of Tonto Creek in the roadless area.

\section{Yttrium}

Authigenic xenotime (yttrium phosphate) occurs in the Apache Group capping Diamond Butte one mile east of the roadless area (Gastil, 1954). Drainage-sediment samples from the southeast slope of Diamond Butte, apparently beneath the xenotime occurrence, do not contain anomalous yttrium.

\section{GEOPHYSICS}

A complete Bouguer gravity map and ar aeromagnetic map (flight level 1,000-ft terrain clearance) were constructed for the Tonto Basin area. For the most part, the maps systematically reflect mapped rock types and generally confirm the interpretive projections of these rock types to depths of $10,000 \mathrm{ft}$ (structural cross sections, Conway, 1976). The major geophysical features trend northeastward, reflecting the Proterozoic structural grain.

The major features of the Hells Gate gravity map are gravity lows in the northern two-thirds of the area, a response to low-density granite, granophyre, and rhyolite. An increase in gravity values southward reflects the more dense sedimentary and volcanic rocks stratigraphically beneath the rhyolite. The lowest gravity values define a crude gravity trough trending northeastward over the Tonto Basin syncline which is underlain by several thousand feet of low-density quartzite and rhyolite. Northwestward-trenting gradients southeast of the roadless area probably reflect stratigraphic and structural complexities.

The aeromagnetic map has more resolution, relative to 
geologic features, than the gravity map. A series of northeasterly alined magnetic lows conform with thick quartzite and rhyolite and mark the axis of the Tonto Basin syricline. A parallel magnetic ridge immediately southeast of the roadless area coincides with a thick section of mafic volcanic rocks in an anticline. A parallel magnetic trough lying farther to the southeast and across a major northeast-trending Proterozoic fault overlies rhyolite.

Magnetic highs in the Green Valley Hills in the northwestern part of the roadless area coincide closely with a subunit of the intrusive rhyolite which contains mafic xenoliths. The broad magnetic high is presumably due to the xenoliths, but sharp internal magnetic peaks may indicate mafic bodies, possibly the source of the xenoliths, in the subsurface. In granite, west of the Hells Gate Roadless Area, some local magnetic highs are due to small Tertiary basaltic plugs (not shown on accompanying map); others are unexplained. The northwest-trending intrusive contact between the granite and the diorite-gabbro body to the southwest is marked by a strong gradient between a magnetic trough to the northeast and a magnetic ridge to the southwest. Field relations indicate the granite and diorite-gabbro contact dips gently southward. Anomalies with strong gradients over this contact are also conspicuous features on regional gravity (West and Sumner, 1973) and aeromagnetic (Sauck and Sumner, 1970) maps.

Geophysical features show no apparent relation to potentially mineralized zones in the Hells Gate area except that locally they weakly reflect the Miocene faults. West of the Hells Gate Roadless Area there is a pronounced embayment into the east margin of the magnetic high over the diorite-gabbro body. This magnetic low coincides with the Royal Flush mine area and may be due to alteration associated with mineralization and (or) faulting, or, alternatively, to the presence of pendants (incompletely mapped just southward) low in magnetic minerals.

\section{MINING DISTRICTS AND MINERALIZATION}

A search was made of all public mining and claim records and of literature pertaining to mineralization in the Hells Gate Roadless Area and vicinity (McColly, 1982). All known mines, prospects, and mineralized areas inside or within a mile of the roadless-area boundary were examined and sampled. In addition, several mines and prospects 2 to 5 $\mathrm{mi}$ from the area were visited and sampled to obtain comparative data.

The Hells Gate Roadless Area has no history of mining or mineral production, and no active mines, claims, or prospects were found. Some prospecting is indicated from a review of mining-claim records in the Gila County courthouse. Approximately 50 mining claims were found with descriptions that could place them within the roadless area, but descriptions are often vague or even contradictory. Most of these claims were filed before the early 1930 's, and none more recently than the 1950 's. U.S. Bureau of Land Management records show no mineral leases, permits, or mining claims active in the area as of September 1982.

\section{MINING DIIS'TRICTS AND MINERALIZED AREAS}

Parts of the Green Valley (Payson) and the Spring Creek (Young) mining districts extend into the Hells Gate Roadless Area, but none of the recorded mineral production from either district can be attributed to the roadless area. Mine workings at the Gisela (Spook) barite mine and in Bearhide Canyon constitute the only mining within $2 \mathrm{mi}$ of the area. Several mineral occurrences within a 5-mi radius include agate, amethyst, barite, beryllium, copper, gold, iron, yttrium, silver, and uranium. These occurrences, locations, and host rocks are given in the list of mines and prospects on the accompanying map sheet and are briefly described below.

\section{Gisela (Spook) barite mine}

A 2- to 4-ft-wide barite vein occurs along a fault between granite and diorite at the Gisela (Spook) barite mine $2 \mathrm{mi}$ west of the roadless area. Production occurred as recently as 1981. Stewart and Pfister (1960, p. 15-16) cite values for the ore of 93.6 percent $\mathrm{BaSO}_{4}, 3.7$ percent $\mathrm{Si}_{2}$, and 0.5 percent $\mathrm{Fe}_{2}{ }_{3}$, with a specific gravity of 4.29 . The vein was originally exposed for over $100 \mathrm{ft}$ along a ridg? top, but in April 1982 it was totally covered with earth and dump material and the site was rehabilitated and seeded. Small pieces of barite float were found where the mine had been. Stewart and Pfister (1960, p. 12) considered this vein to be part of a system of subparallel fractures containing barite that extends south of Payson for about $15 \mathrm{mi}$. As mapped by Conway (1976), the Willow Spring fault, which contairs the barite at the Spook deposit, continues southeastward for at least $2 \mathrm{mi}$ extending into the Hells Gate Roadless Aree. No barite was found along the projection of this fault withir onehalf mile of the pit.

\section{Bearhide Canyon prospect}

Two water-filled shafts and a few shallow surface workings occur along a $1 / 2-\mathrm{mi}$ stretch of Bearhide Canyon just north of the roadless area. None appear to have been worked recently. Samples of mineralized dump material contain as much as $4 \mathrm{ppm}$ gold and $60 \mathrm{ppm}$ silver. Minor amounts of azurite and malachite were found on some of the dumps, but neither was observed in place. Mineralizat:on is associated with quartz veins and pods occurring in granite. There is no recorded production and if any prodiction occurred it was probably minor.

\section{Mud Spring prospect}

A prospect pit on a small quartz vein in altered granite occurs at Mud Spring (area 3) one mile west of the roadless area. Samples of mineralized rock contain as much a $\mathbf{5 0 0}$ ppm silver, 1.7 percent lead, 1 percent arsenic, $300 \mathrm{ppm}$ zine, $50 \mathrm{ppm}$ antimony, $0.5 \mathrm{ppm}$ tellurium, and $140 \mathrm{ppm}$ bismuth. This occurrence is the only mineralized greisen-like zone found in the felsic igneous rocks in the study area. It is in the area of low resource potential for tin $\left(\mathrm{Sn}_{1}\right)$, as defined by drainage-sediment geochemistry, but the drainage in which it occurs was not sampled. The mineralized samples at the prospect are not enriched in the tin-suite elements. A tourmaline-bearing phase of the granite is exposed about 300 $\mathrm{ft}$ west of the prospect. Near the prospect, mostly southward, granite and granophyre are locally sericitized or, rarely, tourmalinized. Small heavily oxidized areas containing iron oxide minerals replacing pyrite alsc are exposed in the granite.

\section{Other mines and mineral occurrences}

Mines and prospects of the Spring Creek mining district south and east of the roadless area are in Early Prcterozoic stratified rocks that are not exposed within the roedless area. Most prospects are in small precious- and base-metal occurrences in fault-associated quartz veins or in $r$ ighly foliated and sheared fine-grained incompetent rocks (see list of mines and prospects, accompanying map sheet). Exceptions are the Fred Pranty mine which may be in a basemetal massive sulfide deposit (M. E. Donnelly, oral corm mun. 1981) and the Breadpan Canyon beryllium prospect, which is associated with shearing near a major northeast-trending Proterozoic fault, but which has no base- or precious-metal enrichment.

Mineralized samples from most of these occurrences were analyzed; the analyses indicate that the base- and precious-metal occurrences were explored primarily for gold, silver, and copper, or combinations thereof. Lead and zinc are moderately enriched at a mine near Ernie Tank. These deposits are also commonly enriched in arsenic, boron, tellurium, antimony, and mercury.

The Royal Flush mine west of the roadless aree was not examined. Metals sought in this area were coppe and possibly gold (Lausen and Wilson, 1925). Mineralization is probably similar to that in the diorite west and south of Payson where metal-bearing quartz veins are localized on Miocene faults and, to a lesser degree, along Proterzzoic faults (C. M. Conway, unpub. data, 1980). 
Mineral occurrences (list of mines and prospects) found in Late Proterozoic or Paleozoic strata near the Hells Gate Roadless Area were not examined.

\section{ANALYSIS OF THE MINERALIZATION}

\section{THE PROTEROZOIC MAGMATIC SYSTEM}

The distributions of the lithophile elements tin, beryllium, lanthanum, niobium, and yttrium in the panned concentrates from the Hells Gate Roadless Area clearly indicate that the silicic alkalic rocks are enriched in these metals and that the greatest enrichments are in the upper parts of the granite body and possibly in the granophyre. All the silicic units in the area are similar in composition and appear to have formed from highly evolved, volatile-rich magmas, but the granite and granophyre appear to be exceptional in this regard. The large granite body likely differentiated in place as indicated by compositional gradation in major oxides and evidence for upward accumulation of volatiles (Conway, 1976). Ubiquitous miarolitic cavities are evidence of exsolution of volatiles in the granophyre. There can be little doubt that the anomalous metal content of these rocks is the result of magmatic processes, either extreme differentiation or very limited partial melting or a combination thereof. However, evidence for ultimate concentration of the tin by the magmatic (or magmatic-hydrothermal) system into greisen zones has not yet been found.

The question arises whether the Mud Spring greisen(?), which is not enriched in the tin suite, is related to the emplacement and cooling of the felsic igneous rocks. Given the well-known phenomenon of metal zonation in ore deposits, it is possible that the metals found at Mud Spring might belong to an outer mineralized zone with tin concentrated in an inner or lower zone. This may be unielated to the apparent concentration of tin (area $\mathrm{Sn}_{1}$ ) in the immediate vicinity of Mud Spring, but would require a complex history of multiple episodes of granite magma-related mineralization. Likewise, the mineral occurrences south of the Hells Gate Roadless Area may also be high-level products of a tin-mineralizing system, again genetically related to granite. Enrichments of major and trace metals ( $\mathrm{Ag}, \mathrm{Pb}, \mathrm{As}, \mathrm{Sb}$, and $\mathrm{Te}$ ) in these occurrences arc similar to the Mud Spring metal suite and support a common origin. Concentration of beryllium, one of the tin-suite elements, in Breadpan Canyon may also support this model.

Other lines of evidence sugrest that the mineralization south of the Hells Gate Roadless Area, and possibly that at Mud Spring, is not related to emplacement and cooling of granite. Heterogeneity among the southern deposits favors multiple causes of origin. As stated above the deposit at the Fred Pranty mine may be volcanogenic. Most of the occurrences are many miles from exposures of the alkali granite and are hundreds of feet down section and laterally far removed from the known site of granite intrusion (Conway, 1976). Mineralization at Mud Spring and also at Bearhide Canyon is possibly related to the systern of northeast-trending Proterozoic faults in the area. Mineralization clearly related to this fault system was not found within the Hells Gate Roadless Area, but the Deadman fault, interpreted to belong to this fault system (Conway and others, 1982), is mineralized in the Mazatzal Wilderness $20 \mathrm{mi}$ to the west (Wrucke and others, 1983). These faults formed after the folding and thrust faulting in the region and must therefore considerably postdate the intrusion and consolidation of the regional alkali granite complex. Therefore, any mineralization on these faults must be unrelated to alkali magmatism and related processes.

The silicic volcanic and hypabyssal complex exposed in Tonto Basin extends westward into the northern Mazatzal Mountains where panned concentrates also yielded anomalously high amounts of tin-suite elements (Wrucke and others, 1983). Base- and precious-metal mineralization also occurs both in alkali granite and in volcanic and voleaniclastic rocks to the south. Some mineralization in these stratified rocks is clearly volcanogenic (Conway, 1983). The types and distributions of mineralization in the Mazatzal Mountains are analogous to those in the Tonto Basin. Wrucke and others
(1983) suggested that the tin and the base- and preciousmetal mineralization in the granite, and in some cases in the stratified rocks, may be attributed to the granite.

Metal provinces or belts in which certain trace elements in sulfides are high regardless of age or type of mineralization occur in the southwestern U.S. and Mexico (Burnham, 1959). These belts apparently reflect deep crustal characteristics. The Tonto Basin-Mazatzal Mountains area lies on a northwest-trending regional belt defined by high amounts of tin in chalcopyrite. The highest value $(8,000 \mathrm{ppm})$ of tin in chalcopyrite in the southwestern U.S. and Mexico comes from the northeastern Mazatzal Mountains (Burnham, 1959). These data may be important in evaluating the metallogenesis of the Tonto Basin-Mazatzal Mountains region. Similarities in major- and trace-metal contents of mineral occurrences in the granite and in the stratified rocks to the south may reflect a unique crustal metal chemistry underlying a "Burnham" mineral belt and do not necessarily support a common origin related to mineralizing action within and immediately above the high-level granitic rocks.

\section{TERTIARY FAULTING AND MAGMATISM}

The occurrence of barite veins along or in close proximity to late Miocene faults, and high barium values from panned concentrates in zones closely coincident with these faults, requires a mineralizing process controlled at least in part by the faults. The panned-concentrate data also suggest that tungsten and possibly lead were concentrated along these faults.

Metal-bearing solutions presumably rose along the porous fault zones and, upon cooling, precipitated barite and associated metals. In central Arizona, partic larly west of Tonto Basin, there was extensive late Miocene volcanic activity. Although only a few basalt plugs are present in the vicinity west of Hells Gate Roadless Area, the magmatic episode may have provided enough heat to generate the late Miocene mineralization. Gold mineralization in the dioritegabbro complex south and west of Payson was controlled in part by the same system of faults and likely wøs generated in the same episode. Possibly the barium, tungsten, and lead were dissolved by waters circulating through tre granite, and the gold by waters circulating through the diorite. Tungsten is commonly associated with tin (Rose and others, 1979; Taylor, 1979) and, although it was not found to be anomalous in the drainage-sediment study, it may have be on sufficiently enriched in the granite to allow ready extraction for a secondary enrichment.

Anomalous amounts of mercury were found in a few of the southern precious- and base-metal occurrerces. Mercury deposits in roughly equivalent strata in the certral Mazatzal Mountains were probably formed as a result of late Tertiary volcanic activity (Ransome, 1915; Faick, 1958; Wrucke and others, 1983). Possibly some of the base- and frecious-metal mineralization south of the Hells Gate Roadless Area is also late Tertiary in age.

\section{ASSESSMENT OF MINERAL RESOURCE POTENTIAL}

There has been no mining and little prospecting and claim filing in the Hells Gate Roadless Area. Nevertheless, findings of this study indicate there is a low potential for several resources, notably tin, in the area (fig. $\Sigma$ ).

The roadless area is largely underlain br a regionally extensive suite of silicic alkalic igneous rocks. The magmatically evolved compositions of these rocks, the widespread fluorite, the local occurrence of the volatile- and lithophilerich minerals topaz and tourmaline, and the evidence for vapor exsolution and hydrothermal activity are common characteristics of tin-bearing granites in many parts of the world (Taylor, 1979; Evans, 1982). The presene of anomalous tin in the silicic alkalic rocks, both in the Hells Gate area and in the Mazatzal Wilderness, is demonstrated by analysis of drainage sediments. The resource potential for tin and associated metals is low. Upper parts of the granite and the overlying granophyre, which have the greatest potential for tin, crop out along the north and southwest margins of the roadless area and dip beneath it. This zone sho'ld be further 
examined for the presence of greisen-type mineralization. In particular, small aplite selvages apparently derived from the granophyre (Conway, 1976) have potential because of presumed extreme differentiation.

Barite is present along Miocene faults near the roadless area, and barium anomalies from drainage sediments along faults within the area likely reflect barite mineralization. Tungsten and lead anomalies, also approximately coincident with the faults, suggest the possibility of concentrations of these elements. The likelihood of resources of these commodities is low.

A moderate resource potential exists for copper, silver, and gold in volcanic and volcaniclastic rocks near the south and east margins of the roadless area, but resource potential for these metals within the roadless area is low because the stratified rocks are not present.

\section{REFERENCES CITED}

Burnham, C. W., 1959, Metallogenic provinces of the southwestern United States and northern Mexico: New Mexico Bureau of Mines and Mineral Resources Bulletin $65,76 \mathrm{p}$.

Burt, D. M., Sheridan, M. F., Bikun, J. F., and Christiansen, E. H., 1982, Topaz rhyolites - distribution, origin, and significance for exploration: Economic Geology 77, 8 , 1818-1836.

Conway, C. M., 1976, Petrology, structure, and evolution of a Precambrian volcanic and plutonic complex, Tonto Basin, Gila County, Arizona: California Institute of Technology, Pasadena, Ph.D. Dissertation, 460 p. 1983, Volcanogenic mineralization at Copper Camp Creek and the potential for massive sulfide deposits in the proterozoic Alder Formation, Arizona: Geological Society of America Abstracts with Programs, v. 15, no. 5 , p. 298.

Conway, C. M., Wrucke, C. T., Ludwig, K. R., and Silver, L. T., 1982, Structures of the Proterozoic Mazatzal orogeny, Arizona: Geological Society of America Abstracts with Programs, v. 14, no. 4, p. 156.

Darton, N. H., 1925, A resume of Arizona geology: Arizona Bureau of Mines Bulletin 119, Geological Series no. 3.

Evans, A. M. (ed.), 1982, Metallization associated with acid magmatism: John Wiley and Sons, New York, 385 p.

Faick, J. N., 1958, Geology of the Ord mine, Mazatzal Mountains quicksilver district, Arizona: U.S. Geological Survey Bulletin 1042-R, p. R685-R698.
Gastil, R. G., 1954, An occurrence of authigenic xenotime: Journal of Sedimentary Petrology, v. 24, no. 4, p. 28081.

1958, Older Precambrian rocks of the Diamcnd Butte quadrangle, Gila County, Arizona: Bulletin Geological Society of America, v. 69, 1495-1514.

Lausen, Carl, and Wilson, E. D., 1925, Gold and copper deposits near Payson, Arizona: University of Arizona, Arizona Bureau of Mines Bulletin 120, $44 \mathrm{p}$.

Ludwig, K. R., 1974, Precambrian geology of the central Mazatzal Mountains: California Institute of Technology, Pasadena, Ph. D. Dissertation, part I, $218 \mathrm{p}$.

MeColly, R. A., 1982, Mineral investigation of the H?lls Gate Roadless Area, Gila County, Arizona: U.S. Pureau of Mines Mineral Land Assessment MLA 139-82.

Putman, G. W., and Burnham, C. W., 1963, Trace elements in igneous rocks, northwestern and central Arizona: Geochimica et cosmochimica Acta., v. 27, p. 53-106.

Ransome, F. L., 1915, Quicksilver deposits of the Mazatzal Range, Arizona: U.S. Geological Survey Bull atin 620, p. 111-128.

Rose, A. W., Hawkes, H. E., and Webb, J. S., 1979, Geochemistry in mineral exploration: New York, Academic Press, $657 \mathrm{p}$.

Sauck, W. A., and Sumner, J. S. 1970, Residual aero'nagnetic map of Arizona: Tucson, University of Arizona, Departinent of Geosciences, scale 1:1,000,000.

Stewart, L. A., and Pfister, A. J., 1960, Barite deposits of Arizona: U.S. Bureau of Mines Reports of I'vestigations RI 5651, $89 \mathrm{p}$.

Taylor, R. G., 1979, Geology of tin deposits: New York, Elsevier, $543 \mathrm{p}$.

West, R. E., and Sumner, J. S., 1973, Bouguer gravity anomaly map of Arizona: Tueson, University of Arizona, Department of Geosciences, seale 1:500,000.

Wilson, E. D., 1922, Proterozoic Mazatzal Quartzite. of central Arizona: Pan American Geologist, v. $3 \varepsilon$. p. 299312 .

1939, Precambrian Mazatzal revolution in certral Arizona: Bulletin Geological Survey of America, v. 50, no. 7 , p. 1113-1163

Wrucke, C. T., Marsh, S. P., Conway, C. M., Ellis, C. E., Kulik, D. M., Moss, C. K., and Raines, G. L., 1983, Mineral resource potential of the Mazatzal Wilderness and contiguous roadless areas, Gila, Maricopa, and Yavapai Counties, Arizona. U.S. Geological Survey Miscellaneous Field Studies Map MF-1573-A, scale $1: 48,000$. 


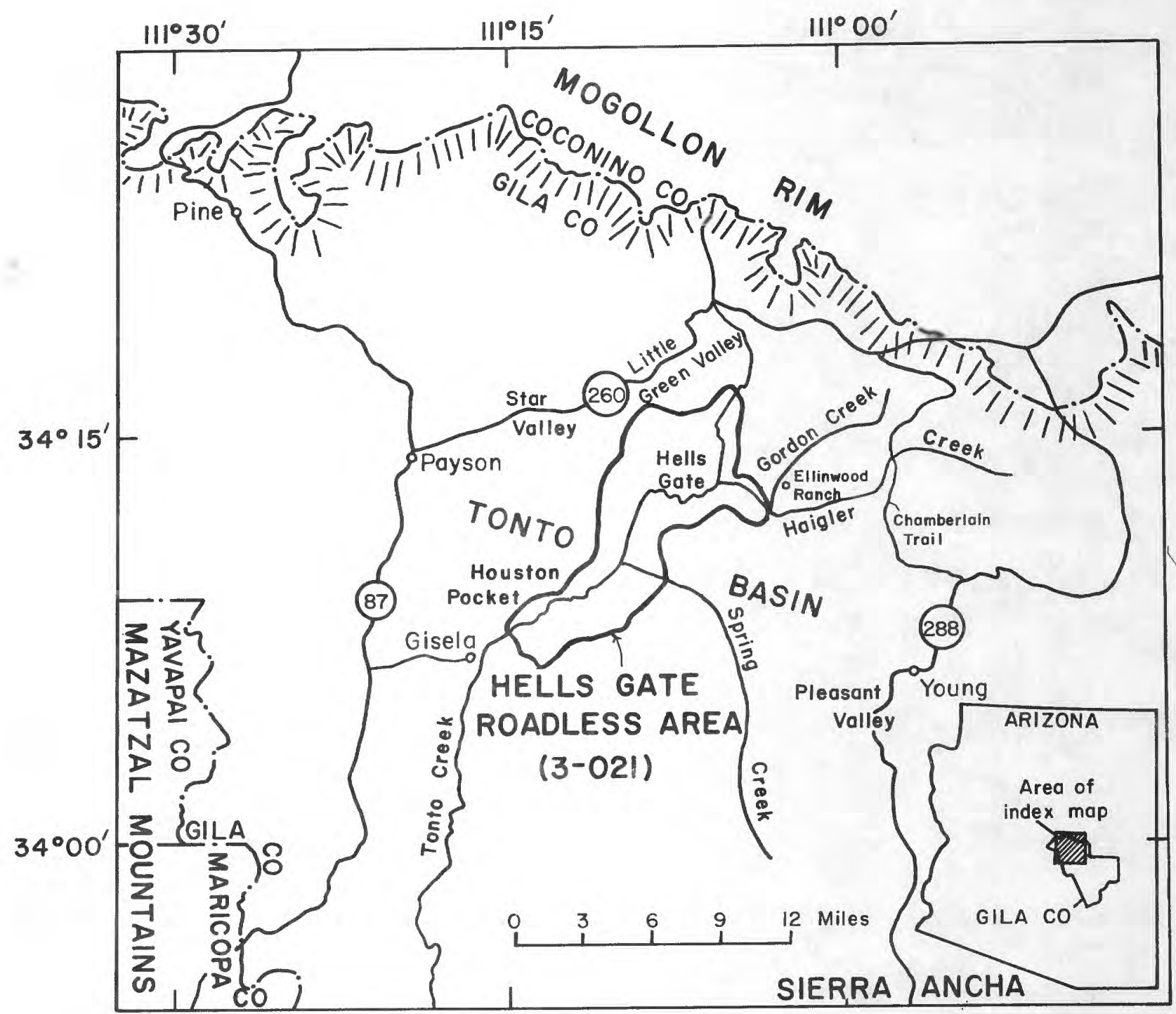

Figure 1.-Index map showing location of Hells Gate Roadless Area, northern Gila County, Ariz. 


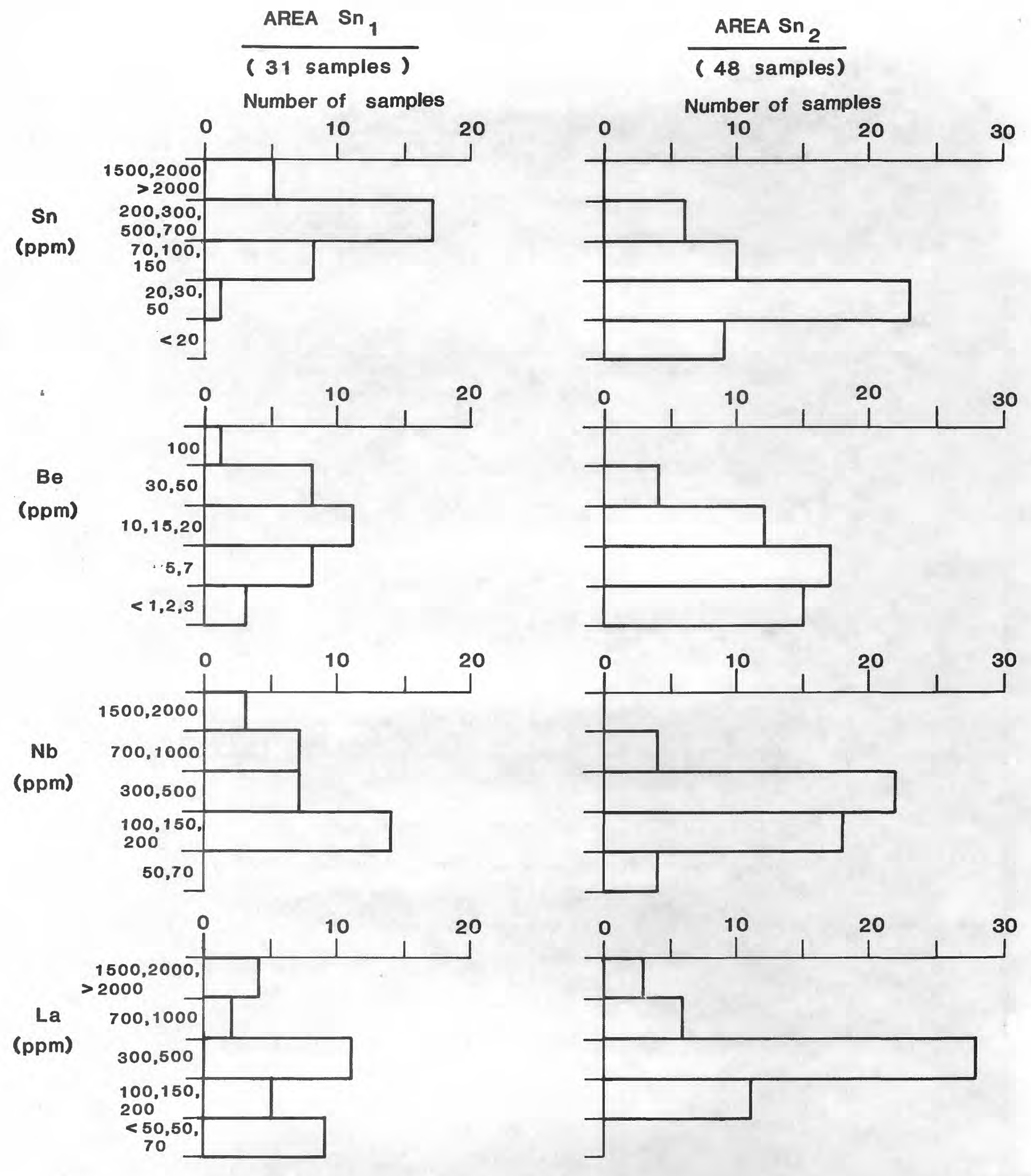

Figure 2.-Histograms showing comparative abundances of tin, beryllium, niobium, and lanthanum in panned-concentrate samples from areas of low to moderate $\left(\mathrm{Sn}_{1}\right)$ and low $\left(\mathrm{Sn}_{2}\right)$ resource potential for tin. 
EXPLANATION

$5 n$, Area with low to moderate resource potential for

$-\frac{\mathrm{Sn}_{1}}{\mathrm{Sn}_{2}}$ Area with low resource potential for tin Ba ${ }_{\lambda} \begin{gathered}\text { Area with low resource potential for } \\ \text { barite }\end{gathered}$

$\Longrightarrow$ Area with low resource potential

Area of geochemical anomaly

Approximate boundary of
Hells Gate Roadless
Area

$x \quad$ Mine or prospect--

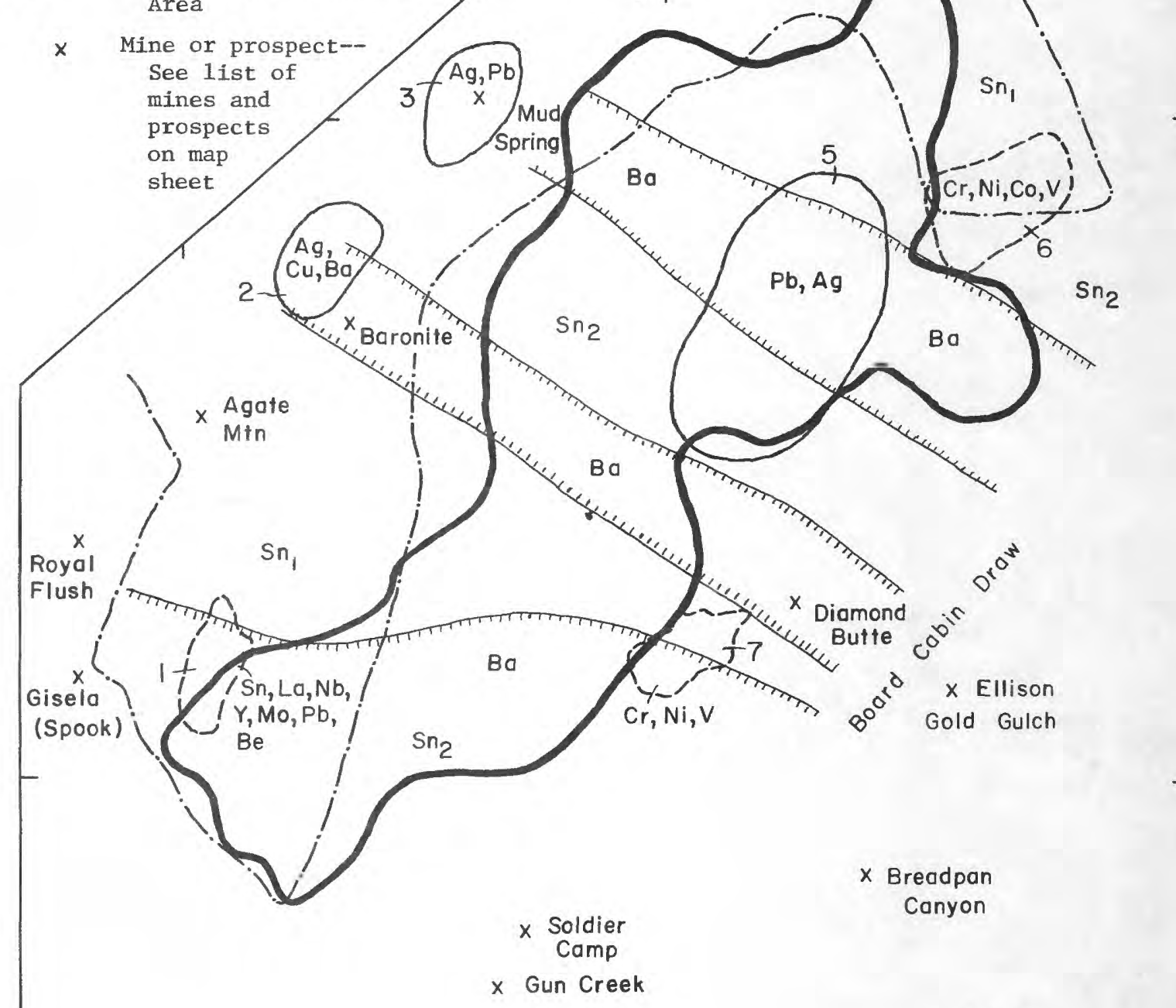

$\times$ Spring

Fred
Pantry

Creek

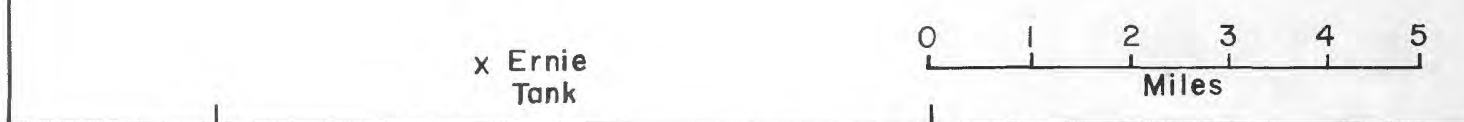

Figure 3.-Areas with mineral resource potential in and near the Hells Gate Roadless Area. Numbers 1-7 refer to explanation on map sheet. 
TABLE 1. SUMMARY OF ANALYSES OF PANNED CONCENTRATES FOR ELEMENTS OF INTEREST

[Values above the bar in each column are considered "high" or "anomalous" as discussed in text and in explanation of accompanying map; numbers in parentheses are determination limits; $\%$ - percent; ppm - parts per million; no. - number of analyses; m - median; L - detected, but below 1imit of determination; $\mathrm{N}$ - not detected; G - greater than]
As (500)
B (20)
Ba (50)
$\mathrm{Be}(2)$
Bi (20)
$\mathrm{Ca}(0.1)$
$\mathrm{Cu}$ (10)
La (50)

\begin{tabular}{|c|c|c|c|c|c|c|c|c|c|}
\hline $\mathrm{ppm}$ & no. & ppm & no. & $\mathrm{ppm}$ & no. & ppm & no. & $\mathrm{ppm}$ & no. \\
\hline 7,000 & 3 & 200 & 1 & $\mathrm{G} 10,000$ & 13 & 100 & 1 & 500 & 1 \\
\hline 2,000 & 1 & 150 & 8 & 10,000 & 9 & 50 & 8 & 300 & 2 \\
\hline 1,500 & 3 & 100 & 14 & 7,000 & 1 & 30 & 4 & 200 & 3 \\
\hline 700 & 1 & $\overline{70 m}$ & 24 & 5,000 & 7 & 20 & 4 & 100 & 1 \\
\hline \multirow[t]{8}{*}{$\mathrm{Nm}$} & 71 & 50 & 18 & 3,000 & 4 & 15 & 7 & 70 & 1 \\
\hline & & 30 & 9 & 2,000 & 5 & 10 & 12 & 50 & 2 \\
\hline & & 20 & 5 & $1,500 \mathrm{~m}$ & 8 & $7 \mathrm{~m}$ & 11 & 30 & 5 \\
\hline & & & & 1,000 & 13 & 5 & 16 & 20 & 3 \\
\hline & & & & 700 & 9 & 3 & 9 & $\mathrm{~L}$ & 11 \\
\hline & & & & 500 & 8 & 2 & 4 & $\mathrm{Nm}$ & 50 \\
\hline & & & & 300 & 1 & L & 3 & & \\
\hline & & & & 200 & 1 & & & & \\
\hline
\end{tabular}

$\begin{array}{lrrrrr}20 & \frac{\text { no. }}{\%} & \text { ppm } & \text { no. } & \text { ppm } & \text { no. } \\ 15 & 2 & 2,000 & 1 & \text { G2,000 } & \text { 1 } \\ 10 & 4 & 5000 & 2 & 2,000 & 4 \\ \frac{10}{5} & 3 & 300 & 1 & 1,000 & 4 \\ 3 & 10 & 200 & 2 & 700 & 4 \\ 2 & 11 & 150 & 3 & 500 & 14 \\ 1.5 & 8 & 100 & 5 & 300 \mathrm{~m} & 25 \\ 1.0 \mathrm{~m} & 10 & 70 & 7 & 200 & 12 \\ 0.7 & 1 & 50 & 9 & 150 & 1 \\ 0.5 & 9 & 30 \mathrm{~m} & 14 & 100 & 3 \\ 0.3 & 4 & 20 & 12 & 70 & 1 \\ 0.2 & 7 & 15 & 10 & 50 & 1 \\ 0.15 & 5 & 10 & 8 & \mathrm{~L} & 4 \\ 0.1 & 3 & \mathrm{~L} & 2 & \mathrm{~N} & 3 \\ \text { L } & 1 & & & & \end{array}$

\begin{tabular}{lrrr} 
Mg & $(.05)$ & Mo & $(10)$ \\
$\frac{10}{10}$ & $\frac{\text { no. }}{1}$ & $\frac{\text { ppm }}{300}$ & $\frac{\text { no. }}{1}$ \\
5 & 1 & 70 & 1 \\
\hline 1 & 4 & $\frac{50}{30}$ & 1 \\
0.7 & 11 & 7 \\
0.5 & 16 & 20 & 6 \\
$0.3 \mathrm{~m}$ & 2.1 & 15 & 6 \\
0.2 & 19 & 10 & 16 \\
0.15 & 2 & Lm & 6 \\
0.1 & 4 & N & 35
\end{tabular}

\begin{tabular}{cr} 
Nb & $(50)$ \\
$2, \frac{\text { ppm }}{2}$ & $\frac{\text { no. }}{1}$ \\
1,500 & 2 \\
1,000 & 1 \\
700 & 10 \\
500 & 15 \\
\hline $300 m$ & 14 \\
200 & 12 \\
150 & 12 \\
100 & 8 \\
70 & 4
\end{tabular}

\begin{tabular}{cr}
$\mathrm{Pb}$ & (20) \\
$\mathrm{ppm}$ & $\frac{\mathrm{no}}{1}$ \\
20,000 & 1 \\
10,000 & 1 \\
5,000 & 1 \\
3,000 & 2 \\
2,000 & 1 \\
1,000 & 1 \\
700 & 4 \\
500 & 11 \\
\hline 300 & 8 \\
$200 \mathrm{~m}$ & 13 \\
150 & 10 \\
100 & 12 \\
70 & 8 \\
50 & 4 \\
30 & 1 \\
20 & 1
\end{tabular}

Sn (20)

Th (200)

W (100)

Y (20)

70

$$
\begin{array}{cr}
\text { ppm } & \text { no. } \\
2,000 & \frac{n}{2} \\
1,500 & 2 \\
700 & 1 \\
500 & 3 \\
500 & 7 \\
300 & 9 \\
200 & 4 \\
150 & 7 \\
100 \mathrm{~m} & 5 \\
70 & 6 \\
\hline 50 & 10 \\
30 & 8 \\
20 & 6 \\
\mathrm{~L} & 3 \\
\mathrm{~N} & 6
\end{array}
$$

\begin{tabular}{|c|c|c|c|}
\hline $\mathrm{ppm}$ & no. & $\mathrm{ppm}$ & no \\
\hline 500 & 1 & $\mathrm{G5}, 000$ & 1 \\
\hline 150 & 1 & 5000 & 2 \\
\hline 100 & 11 & 3000 & 3 \\
\hline L & 14 & 2000 & 6 \\
\hline \multirow[t]{7}{*}{$\mathrm{Nm}$} & 52 & 1,500 & 9 \\
\hline & & 1,000 & 13 \\
\hline & & 700 & 10 \\
\hline & & 500 & 24 \\
\hline & & 300 & 6 \\
\hline & & 200 & 4 \\
\hline & & 100 & 1 \\
\hline
\end{tabular}

\begin{tabular}{|c|c|c|c|c|c|c|c|c|c|c|c|c|c|c|c|c|c|c|c|}
\hline \multirow{2}{*}{$\begin{array}{r}\mathrm{Ag} \\
\mathrm{ppm}\end{array}$} & \multirow{2}{*}{$\begin{array}{c}.5) \\
\text { no. }\end{array}$} & \multicolumn{2}{|c|}{ B (10) } & \multicolumn{2}{|c|}{$\mathrm{Ba}(20)$} & \multicolumn{2}{|c|}{$\mathrm{Ca}(.05)$} & \multicolumn{2}{|c|}{$\operatorname{Cr}(10)$} & \multicolumn{2}{|c|}{ Co (5) } & \multicolumn{2}{|c|}{$\mathrm{Cu}$ (5) } & \multicolumn{2}{|c|}{$\mathrm{Fe}(.05)$} & \multicolumn{2}{|c|}{$\mathrm{La}(20)$} & \multicolumn{2}{|c|}{$\mathrm{Mg}(.02)$} \\
\hline & & ppm & no. & ppm & no. & $\%$ & no. & ppm & no. & ppm & no. & ppm & no. & $\%$ & no. & $\mathrm{ppm}$ & no. & $\%$ & no. \\
\hline 1.5 & $\overline{2}$ & 100 & $\overline{3}$ & 2,000 & 1 & $\overline{5}$ & $\frac{1}{3}$ & 1,500 & 1 & 30 & 3 & 500 & $\frac{\pi}{2}$ & $2 \overline{0}$ & 1 & 500 & 1 & $\overline{3}$ & 2 \\
\hline 0.7 & 2 & 70 & 11 & 1,500 & 10 & 3 & 1 & 700 & 2 & 20 & 3 & 100 & 1 & 15 & 3 & 300 & 1 & 1.5 & 3 \\
\hline 0.5 & 7 & $50 \mathrm{~m}$ & 36 & $1,000 \mathrm{~m}$ & 47 & 2 & 1 & 300 & 3 & 15 & 15 & 70 & 9 & $\overline{10}$ & 15 & 200 & 3 & 1.0 & 13 \\
\hline $\bar{L}$ & 3 & 30 & 23 & 700 & 21 & 1 & 6 & $\overline{200}$ & 5 & $10 \mathrm{~m}$ & 26 & 50 & 25 & 7 & 16 & 150 & 16 & $0.7 \mathrm{~m}$ & 27 \\
\hline $\mathrm{Nm}$ & 71 & 20 & 11 & 500 & 3 & 0.7 & 12 & 150 & 13 & 7 & 28 & $30 \mathrm{~m}$ & 21 & $5 \mathrm{~m}$ & 25 & $100 \mathrm{~m}$ & 27 & 0.5 & 34 \\
\hline & & L & 1 & 300 & 3 & $0.5 \mathrm{~m}$ & 19 & $100 \mathrm{~m}$ & 28 & 5 & 10 & 20 & 12 & 3 & 24 & 70 & 15 & 0.3 & 5 \\
\hline & & & & & & 0.3 & 9 & 70 & 18 & & & 15 & 9 & 2 & 1 & 50 & 15 & 0.2 & 1 \\
\hline & & & & & & 0.2 & 18 & 50 & 13 & & & 10 & 5 & L & 3 & & & & \\
\hline & & & & & & 0.15 & 5 & 30 & 2 & & & 7 & 1 & $\mathrm{~N}$ & 9 & & & & \\
\hline & & & & & & 0.10 & 9 & & & & & & & & & & & & \\
\hline & & & & & & 0.07 & 2 & & & & & & & & & & & & \\
\hline
\end{tabular}

\begin{tabular}{|c|c|c|c|c|c|c|c|c|c|c|c|c|c|c|c|c|c|}
\hline ppm & no. & ppm & no. & ppm & no. & $\mathrm{ppm}$ & no. & ppm & no. & Ppm & no. & $\mathrm{ppm}$ & no. & ppm & no. & $\mathrm{ppm}$ & no. \\
\hline 5,000 & 1 & 15 & 1 & 70 & 1 & 150 & 1 & 100 & $\overline{1}$ & 30 & 1 & 150 & 1 & 700 & $\overline{1}$ & 500 & $\overline{1}$ \\
\hline 3,000 & 2 & 10 & 1 & 50 & 3 & 100 & 1 & 70 & 4 & 20 & 1 & 100 & 1 & 500 & 2 & 150 & 4 \\
\hline$\overline{2,000}$ & 7 & 7 & 4 & 30 & 12 & 70 & 1 & 50 & 26 & 15 & 3 & $\bar{L}$ & 1 & 300 & 4 & 100 & 8 \\
\hline 1,500 & 25 & 5 & 13 & $20 m$ & 36 & 50 & 6 & $30 \mathrm{~m}$ & 27 & 10 & 1 & $\mathrm{Nm}$ & 82 & $\overline{200}$ & 5 & $70 \mathrm{~m}$ & 31 \\
\hline $1,000 \mathrm{~m}$ & 33 & L & 14 & L & 16 & 30 & 16 & 20 & 21 & $\bar{L}$ & 1 & & & 150 & 12 & 50 & 28 \\
\hline 700 & 11 & $\mathrm{Nm}$ & 52 & $\mathrm{~N}$ & 17 & $20 \mathrm{~m}$ & 29 & 15 & 5 & $\mathrm{Nm}$ & 78 & & & $100 \mathrm{~m}$ & 22 & 30 & 12 \\
\hline 500 & 6 & & & & & 15 & 18 & 10 & 1 & & & & & 70 & 28 & 20 & 1 \\
\hline & & & & & & 10 & 10 & & & & & & & 50 & 9 & & \\
\hline & & & & & & 7 & 2 & & & & & & & 30 & 2 & & \\
\hline & & & & & & 5 & 1 & & & & & & & & & & \\
\hline
\end{tabular}

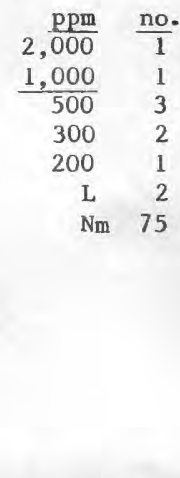

TABLE 2. SUMMARY OF ANALYSES OF BULK SEDIMENTS FOR ELEMENTS OF INTEREST

[Values above the bar in each column are considered "high" or "anomalous" as discussed in text and in explanation of accompanying map; numbers in parentheses are detection limits; \% - percent; ppm - parts per million; no. - number of analyses; m - median; L - detected, but below limit of determination; $\mathrm{N}$ - not detected]

$\mathrm{Mn}(10) \quad \mathrm{Mo}(5) \quad \mathrm{Nb}(20) \quad \mathrm{Ni}(5) \quad \mathrm{Pb}(10) \quad \mathrm{Sn}(10) \quad \mathrm{Th}(100) \quad \mathrm{V}(10) \quad \mathrm{Y}$ (10) 